Інноватика у вихованні. Випуск 12. 2020.

\author{
УДК 37.018.1:[37:1](091)
}

DOI: $\underline{10.35619 / \text { iiu.v1i12.317 }}$

Петренко Оксана

доктор педагогічних наук, професор, завідувач кафедри теорії і методики виховання Рівненського державного гуманітарного університету,

м. Рівне, Україна

ORCID: 0000-0001-6906-3542, e-mail: o.b.petrenko@gmail.com

\title{
ПИТАННЯ СІМЕЙНОГО ВИХОВАННЯ В КОНТЕКСТІ ФІЛОСОФСЬКО-ПЕДАГОГІЧНОЇ СПАДЩИНИ НІМЕЧЧИНИ (СЕРЕДИНА ХVIII -ПОЧАТОК ХХІ СТОЛІТТЯ)
}

Анотація. В статті здійснено цілісний історико-педагогічний аналіз питання сімейного виховання в контексті філософсько-педагогічної спадщини Німеччини з середини XVIII - до початку XXI століття. Оскільки зміст, цілі й методи виховання дитини у сім'ї завжди визначалися й визначаються вимогами часу, специфіка виховання зумовлена рівнем економічного розвитку держави, ідеологічними особливостями, культурою, релігією, які домінують у певній країні, особливо цікавою у цьому контексті є Німеччина, в якій склалася своєрідна система сімейного виховання з унікальними традиціями. Тлумачення сімейного виховання дитини в німецькій філософсько-педагогічній спадщині розвивалося й удосконалювалося відповідно до розвитку німецького суспільства у контексті культури німецького народу.

Схарактеризовано погляди на виховання дитини в німецькій сім'ї філософів і педагогів визначеного періоду (I. Канта, Г. Гегеля, Вільгельма фон Гумбольдта, Й. Ф. Гербарта, А. Дістервега, Ф. Фребеля, Пауля Антона де Лагарда, В. Лайа, Р. Штайнера, Ю. Лангбена, Ф. Кроума, Вільяма Віндельбанда, Отто Вільмана, Густава Адольфа Лінднера, Пауля Наторпа, Гуго Гаудіга, Бертольда Отто, Е. Шпрангера, Зігмунда Бернфельда, Е. Фромма, Рене Кеніга, К. Молленхауера, Ульріха Бека, Хельги Цайхер, Г. Гудджонса, Б. Боїза). На основі здійсненого аналізу зроблено висновок про те, що під впливом ідей видатних філософів та педагогів у Німеччині відбулись якісні зрушення у сприйнятті сімейного виховання: від суворого й аскетичного у Середньовіччі, гуманного в епоху Відродження та Реформації, чітко організованого в епоху Нового Часу та Просвітництва до усвідомлення сімейного виховання як одного 3 найвідповідальніших завдань німецького суспільства на початку XXI ст. 3'ясовано, що проблема сімейного виховання - один 3 найбільш досліджуваних теоретичних аспектів німецької гуманітарної науки, який розробляють сьогодні філософи, педагоги, психологи, соціологи й спеціалісти інших галузей науки.

Ключові слова: сімейне виховання, німецька сім'я, німецька філософія, німецька педагогіка, філософсько-педагогічна спадщина.

Постановка проблеми. Суспільно-політичний розвиток України спрямований на євроінтеграцію, що, своєю чергою, зумовлює осмислення зарубіжного досвіду в усіх царинах функціонування країни, зокрема й в освіті. Увага вчених зосереджена сьогодні на вивченні педагогічних парадигм 
європейських країн з нагромадженим віками виховним потенціалом. У контексті цих тенденцій вивчення питання сімейного виховання в розвинених європейських країнах є актуальним і доцільним. Зміст, методи і цілі виховання дитини у сім’і завжди визначалися й визначаються вимогами часу. Специфіка виховання зумовлена рівнем економічного розвитку держави, ідеологічними особливостями, культурою, релігією, які домінують у певній країні.

Особливо цікавою у цьому контексті нам видається Німеччина, в якій склалася своєрідна система сімейного виховання з унікальними традиціями. Трактування виховання дитини у сім’ї в німецькій філософсько-педагогічній спадщині розвивалось й удосконалювалось відповідно до розвитку німецького суспільства у контексті культури німецького народу. Час збагатив їх найціннішими традиціями, які доцільно вивчати і застосовувати всім іншим народам. На нашу думку, німецька модель сімейного виховання дитини, в основу якого покладено відповідні традиції, може стати своєрідним орієнтиром для модернізації системи сімейного виховання в Україні.

Аналіз останніх досліджень 3 проблеми. Проблема висвітлення ідей виховання, зокрема й сімейного, в спадщині німецьких філософів і педагогів в останні роки була предметом вивчення О. Барило (2004); Г. Чирікова схарактеризувала зміст сімейного виховання молодших школярів в німецькій педагогіці (2011). Тенденції сімейного виховання та систему цінностей в німецькій сучасній педагогіці аналізувала О. Сурженко (2011). Натомість, М. Клим здійснила грунтовний аналіз висвітлення проблеми сімейного виховання у німецьких дослідницьких студіях крізь призму ретроспективного дискурсу кінця XIX - початку XX століття (2014), а Н. Федчишин i О. Пермякова вивчали роль родини й сімейного виховання в організації освітнього процесу Німеччини і Франції (2019).

Однак, попри значну кількість праць, які розкривають різноманітні аспекти сімейного виховання в Німеччині, аналіз питання сімейного виховання в контексті німецької філософсько-педагогічної спадщини XVIII-XXI ст. як цілісна історико-педагогічна проблема системно і комплексно здійснений не був. Таким чином, означений аспект потребує подальшого вивчення 3 урахуванням новітніх праць і публікацій.

Мета статті полягає у здійсненні цілісного історико-педагогічного аналізу спадщини німецьких філософів і педагогів середини XVIII - початку XXI ст. у контексті вирішення ними питання сімейного виховання.

Виклад основного матеріалу дослідження. Ретроспективний аналіз поглядів німецьких філософів і педагогів на питання сімейного виховання здійснимо, починаючи 3 середини XVIII ст., позаяк саме тоді своєрідна соціокультурна ситуація зумовила розвиток нових педагогічних напрямів, в основі яких лежали погляди німецький філософів (Х. Томазій, Х. Вольф й I. Кант).

Засновником та одним 3 провідних ідеологів німецької класичної філософії вважається І. Кант (1724-1804), фундаментальні праці якого («Критика чистого розуму», «Критика здатності судження» та «Про педагогіку») містили обгрунтування нової концепції буття, на основі якої філософ провів розподіл буття на світ природи і світ людини, між якими $є$ як схоже, так і багато відмінностей. У контексті проблеми сімейного виховання цінним $є$ те, що у своїй теорії розвитку людини І. Кант неодноразово наголошував на важливості ролі вихователя у житті дитини. Саме вихователь $з$ перших років життя дитини 
починає закладати фундамент будівлі, яку вона закінчує у процесі життя. Першою сходинкою у вихованні, на думку філософа, є піклування батьків про те, щоб дитина сама собі не зашкодила. Воля малюка повинна обмежуватись авторитетом наставника (Воробьёв і Шачина, 2005, с. 113). Водночас, видатний філософ радив батькам не сприймати дітей як свою власність, а натомість чекати від них тільки одного - подяки за виховання (Кант, 1990, с. 129).

Німецький філософ Г. Гегель (1770-1831), попри зацікавленість глобальними проблемами людства, вагомого значення надавав аналізу проблеми сімейного виховання дітей. Вважаючи любов батьків до дітей першим наслідком взаємної любові батьків, філософ стверджував, що права дитини полягають у тому, щоб отримувати в сім'ї їжу і виховання, а обов'язки - бути слухняною та допомагати батькам у сімейних турботах. Г. Гегель доводив, що у вихованні дітей не можна обійтися тільки добротою і не треба застосовувати переконання. Головним критерієм виховання філософ вважав чітку дисципліну, адже перетворення дитини на самостійну й незалежну особистість потребує розвитку в ній почуття підкорення загальному, що насамперед уособлюють собою батьки (1990, с. 145).

Німецький просвітитель Вільгельм фон Гумбольдт (1767-1835) вважав, що різностороннє формування індивідуальності $є$ шляхетним завданням людства. Гумбольдт стверджував, що «кінцеве завдання нашого існування полягає в тому, щоб дати максимально повний зміст концепції людяності в нашій власній особистості ... через вплив дій у нашому власному житті». Це завдання «може бути реалізоване тільки за допомогою зв'язків, встановлених між нами як особистостями й навколишнім світом» (1992). В. Гумбольдт вважав, що в суспільстві вільних людей і сімейні зв'язки сильніші: батьки 3 більшим бажанням піклуються про дітей і завдяки кращому матеріальному становищу швидше здійснюють свої бажання (1992, с.50).

У німецькій педагогіці XIX століття домінувала авторитарна манера виховання, теоретико-методологічні засади якої сформувалися та набули свого апогею ще в епоху гербартіанства. Як зазначають А. Кузьмінський i В. Омеляненко, на сторінках праці німецького філософа, педагога Й. Ф. Гербарта (1776-1841) «Загальна педагогіка, виведена з цілей виховання» містяться ідеї про застосування у виховному процесі породженого у кожному вихователі непереборного прагнення будь-яким чином обмежити повчання та застереження, що визнається недоліком, є зразком особистісної обмеженості (Кузьмінський та Омеляненко, 2006). Головними поняттями, якими оперував педагог, даючи змогу цілісно зрозуміти серйозність підходу до процесу виховання, є гнучкість мудрості у батьків, самостійність мислення, постійне продумування своїх дій. Спираючись на аналіз величезного фактичного матеріалу, вчений довів, що кожна людина у своєму житті володіє величезним багажем психологічної перспективи, яка необхідна для споглядання дитячої особистості, тобто «різноманітність матеріалу викличе різноманітність суджень, принадливість чергування приведе до надання переваги найкращому...» (Кузьмінський та Омеляненко, 2006, с.338).

Авторитарна парадигма виховання довгий час виконувала роль офіційної державної доктрини в Німеччині. Причиною іiі тривалої стійкості, на думку сучасного дослідника систем виховання В. Лукова, був традиційний патерналізм - «сильний і строгий батько вчить сина правильно жити, і син буде готовий до 
зустрічі 3 життям» (Луков, 2005, с. 140), цілком виправданий - пригнічення дитячої волі та тілесні покарання, проте це не давало належного ефекту.

Протиріччя у структурі системи Гербарта не передбачали готувати молодь до «співпраці» 3 соціумом, а найголовніше - не забезпечували повноцінну дихотомію відносин батьки-діти. А це означає, що переорієнтація у вихованні зумовила реорганізацію усталених норм і сформувала рівноправні відносини у цих малих соціальних групах, у ситуації творення і набуття дитячого життєвого досвіду (Федчишин, 2015).

Німецький педагог А.Дістервег (1790-1866) як один 3 відомих послідовників Й. Песталоцці інтерпретував процес сімейного виховання 3 погляду культуроосмислення історичного розвитку свого народу, місця і часу народження, своїх давніх предків. Ось які вимоги ставив видатний педагог до культуровідповідного виховання: «У процесі виховання варто брати до уваги умови місця і часу, в яких народилася людина і в яких їй призначено жити, одним словом, усю сучасну культуру, а особливо культуру країни, яка $є$ батьківщиною вихованця у всеохоплюючому смислі цього слова» (1956, с. 402).

Головну мету виховання педагог вбачав у гармонійному розвитку усіх можливих задатків людини для «служіння істині, красі і добру». Досягнення цієї головної мети, на думку Дістервега, відбувається через самодіяльність. Він вважав, що правильно і розумно організоване виховання повинне базуватися на трьох принципах: природовідповідності, культуровідповідності та самодіяльності.

Відомий німецький педагог, теоретик дошкільної педагогіки Ф. Фребель (1782-1852) у працях «Виховання людини», «Дитячий садок» зосередив увагу на провідній ролі батьків у розвитку й вихованні дитини. Педагог вважав, що дитину необхідно сприймати як людину, визначаючи батьків первинними вихователями, ставив перед ними завдання «... дивитися на дитину i підтримувати (зберігати) iї у необхідній цілісній гармонії, у ясному співвідношенні і в живому зв'язку 3 сьогоденням, минулим i майбутнім людського розвитку і таким чином привести у єдність, узгодженість і гармонію освіту, виховання дитини з сучасними, минулими i майбутніми вимогами розвитку роду людського» $(1906$, с.4).

Метою виховання Ф. Фребель (2001) вважав розвиток природних здібностей дитини. Виховання повинне сприяти самовиявленню, але останнє неможливе без зовнішніх впливів, тому необхідні різноманітні засоби, які сприяли б розвитку внутрішніх сил, можливостей, талантів. Педагог наголошував, що дитина повинна отримувати піклування і тепло, як рослина в садку.

Німецький історик, професор в Геттінгені Пауль Антон де Лагард (18271891) обстоював прерогативу «батьківського ідеалу, що має на меті здійснити переворот у суспільному майбутньому країни» (Клим, 2014).

Авторитаризм у батьківсько-дитячих стосунках в німецькій сім’і проявляється у надмірній, неконтрольованій навіть насильній вимогливості, виховательській упередженості. Німецький теоретик експериментальної педагогіки В. Лай (1861-1926) орієнтує вихователя на три головні способи виховання - це догляд, дисципліна, освіта. Мету виховання вчений вбачав у сприянні того, щоб вихованець якомога раніше зміг перейти до самовиховання (Коваленко та Бєлкіна, 2006, с. 518). При цьому акцент робиться на тому, що успішна реалізація виховного процесу в колі сім'ї можлива завдяки взаємодії елементів тріади - сприйняття, переробка, вираз, котрі через пристосування до 
оточуючих умов екстраполюються на формування індивідуальної соціалізації та впливають на опанування соціальних ролей. Головним у практиці виховання в сім’ї, на думку В.Лая, $є$ спостережно-речовий матеріал. Саме цим можна забезпечити гармонійний розвиток індивідуальності, іiі культурне сприйняття, застосувати це на благо собі і всього свого оточення (Коваленко та Бєлкіна, 2006, с. 519).

Однак невідповідність і неузгодженість традиційних підходів до освіти й виховної практики вимогам часу наприкінці XIX - на початку XX ст. зумовили зміну провідної детермінанти - з авторитарної на гуманну.

Представники гуманістичної педагогіки Німеччини кінця XIX - першої половини XX століття Л. Гурлітт, І. Глезер, Б. Отто, А.Ліхтварк, Г. Гаудіг, Ю. Лангбен, Г. Вінекен, Е. Кей, Р. Штайнер, П. Петерсен й інші не лише критикували гербартіанську авторитарну педагогіку, сучасну їм школу як таку, що не задовольняла життєві інтереси народу, але й розробили аксіологічні основи педагогіки, переорієнтованої на вільний розвиток особистості, на гуманістичні традиції виховання епохи Відродження. Освіту вони вважали провідним засобом формування гуманної особистості, а особистість розглядали як найвищу цінність суспільства. Гуманістичні ціннісні орієнтації згадані педагоги-реформатори не пов'язували 3 політизацією школи, вони виступали проти ідеологізації освіти й виховання.

Вальдорфська педагогіка, засновником якої вважають німецького філософа, педагога та культуролога Р. Штайнера (1861-1925), є одним з гуманістичних напрямів німецької педагогіки, сутність якого полягає в реалізації ідей вільного виховання. Головною метою цієї педагогіки постає формування цілісної незалежної особистості, яка свідомо прагне до максимальної реалізації своїх можливостей і здатна досягти гармонії власного «Я» 3 навколишнім світом. Тому саме розвитку духу й душі Р. Штайнер (2006) надавав особливого значення. Принциповим у вихованні дітей Р. Штайнер (2006) вважав обмеження обсягу занять, оскільки, на думку педагога, дитина має отримувати емоції від пізнавання світу, а не додаткові теоретичні відомості про нього.

Письменник, педагог Ю. Лангбен (1851-1907) аналізував становлення виховання в німецькій сім'ї від занепаду культури виховання до поступового відродження ідей виховання у сім’ї (Клим, 2014).

Німецький педагог Ф. Кроум у книзі «Про виховання через вихователів» (1923 р.) описав сімейне виховання в традиційній сім'ї: «Щоби діти не мали права скаржитися на батьків, останні повинні присвячувати їм достатньо часу». Він не схвалював традиції багатьох заможних німецьких сімей наймати домашнього вихователя: «Я думаю, що сімейним вихованням дітей повинні опікуватися лише батьки, самостійно добирати доцільні методи та засоби виховного процесу». Протилежна тенденція може спричинити розкол усередині сім’ї, тому що чужі вихователі не можуть добрати адекватні дитині методи. Подруге, домашнє виховання, до якого залучені батьки, забезпечує пріоритет морального виховання, формування якостей духовності - любові до ближнього, милосердя, сили духу та ін.» (Anthroposophische Pädagogik und ihre Voraussentzungen, 1924). Сім'ю Ф. Кроум називав «маленьким будинковим суспільством». У німецьких сім'ях цінували домашне вогнище, свободу та незалежність кожного члена родини. Педагог був прихильним до батьківського авторитаризму в сімейному вихованні, незважаючи на кількість дітей у сім'ї. «Домашні вихователі мають незаперечну перевагу, якщо в батьків надмірна 
зайнятість на роботі». Ф. Кроум був категорично проти того, щоб батьки відправляли дітей у школу до досягнення ними відповідного паспортного віку. Педагог також багато уваги приділяв аналізу змісту сімейного виховання в багатодітних сім'ях.

Професор Берлінської наукової школи Вільям Віндельбанд (1848-1915), який належав до педагогів-традиціоналістів, неодноразово наголошував на ролі школи в домашній освіті. Виховання дітей повинно базуватися на довірі та повазі: «зміст сімейного виховання повинен охоплювати знання про природу дитини». I далі: «Держава самотужки дбає про встановлення змісту сімейного виховання за допомогою чинного законодавства та програм розвитку, проте неправомірно заборонити батькам брати належну участь в організації цього» (Клим, 2014).

Своєю чергою, німецький педагог Отто Вільман (1839-1920) вніс у педагогіку паралелізм індивідуального сімейного i соціального життя, що пояснював як соціальне поєднання родини, держави, народу, релігійної приналежності. Для досягнення цих цілей ставилися такі завдання: виховуюча любов батьків до дитини, забезпечення індивідуального, духовного та фізичного розвитку дитини (Клим, 2014). О. Вільман працював над вивченням функції соціалізації в сімейному вихованні, яка, на думку педагога, повинна відрізнятися політично і суспільно. Спорідненість дитячої особистості і соціальної ролі учений визначав як момент включення в соціальність. Нормативне зіставлення індивідуалізованої автономії і соціалізації як функції спричинить формування культурно-людського ідеалу, - зазначає М. Клим (2014).

3і свого боку, Густав Адольф Лінднер (1828-1887) уклав енциклопедію «Путівник у сімейне виховання», у якій обгрунтовував сімейні цінності на основі учіння Й. Гербарта. Він вважав, що виховання повинне проходити в гармонії з моральним і загальнокультурним розвитком суспільства: «Спільний грунт для утворення соціальної, суспільної обізнаності лежить у будинку, у особливостях етнографічної території. Скрізь, де присутня ця система подій, утворюється відповідне соціальне коло, соціальна обізнаність» (Клим, 2013). Тож, соціальна теорія і практика виховання у Німеччині стала продовженням народної педагогіки, зміст якої пропагував національну ідентичність «ми німці», «ми слов'яни», «ми австрійці» чи «ми католики». Г. А. Лінднер $з$ цього приводу писав, що сімейне виховання репрезентує формування національних почуттів, соціального лідерства, незалежного громадянина, думки якого емансиповані.

Всесвітньо відомий професор філософії та педагогіки з Марбургзького університету Пауль Наторп (1854-1924) розвивав ідеї соціальної педагогіки у контексті народного сімейного виховання. Його творчість пов'язана 3 ідеями неокантіанства. Е. Шпрангер, даючи характеристику науковим досягненням вченого, відзначив, що він «перейняв соціальний дух Й. Ф. Песталоцці, моральну автономію Канта та Платонівський живучий ідеал моральнодержавної спільноти» (Клим, 2013). Праця П. Наторпа «Соціальна педагогіка. Теорія виховання волі на основі спільності» відродила у свідомості німців основи формування моралі у процесі виховання. Особистість і сімейне виховання взаємодіють і неподільні індивідуально у суспільному контексті через персоніфікований досвід. П. Наторп зазначав, що невід'ємним для комплектування змісту сімейного виховання вважається самосвідомість батьків, співвіднесена з батьківським ідейним протиборством (Клим, 2013). 
Німецький педагог Гуго Гаудіг (1860-1923) обгрунтовував принцип культуровідповідності у сімейному вихованні. Він вважав, що метою виховання й самовиховання може бути тільки вільна особистість, а школа повинна орієнтуватися на інтереси цієї особистості, при цьому особистість вихователя $\epsilon$ головним чинником формування особистості дитини (Клим, 2013).

Представник теорії вільного виховання Бертольд Отто (1859-1933) вважав, що сімейне виховання - це мистецтво. I освіта в сім'ї $\epsilon$ основою усього освітнього процесу в подальшому житті дитини. Саме в сім'ї накопичується базовий досвід дитини (Беленцов, 2019).

Німецький філософ Е. Шпрангер (1882-1962) головним у вихованні дитини вважав вибір нею власного місця у соціумі, при цьому чільне місце у виховному процесі відводилося ціннісним орієнтаціям батьків та дітей. Таких учений виокремив шість, серед них й економічний (зі схильністю до господарської діяльності) та теоретичний (активність у здобуванні нових знань) (Клим, 2013).

Педагогічні ідеї німецького педагога-традиціоналіста, уродженця Львова Зігмунда Бернфельда (1892-1953) грунтуються на постулатах фрейдомарксизму. Основна ідея його психоаналітичної педагогіки полягає у тому, що насамперед політика, а не педагогіка, потребує науки про виховання, оскільки мету виховання підростаючого покоління визначає не філософія чи етика, а пануючі соціально-політичні верстви, які керуються власними намірами для зміцнення і розширення владних позицій. Педагогіка ж в межах такої системи уявлень лише маскує процес утримання влади, покриваючи його павутинням нових освітніх ідей, які підганяються під політичні наміри. На його думку, дорослі вважають дитину засобом досягнення теологічної, етичної, політичної або соціальної мети.

Основні погляди на сімейне виховання 3. Бернфельда найбільш повно розкриті у праці «Сізіф і кордони виховання» (1925). Педагог, вивчаючи проблеми сімейного виховання своїх друзів, стверджував, що дитину, навіть у молодшому віці, слід оберігати від конфліктів, а засобами виховання повинна бути саморефлексія, бо репресивні методи виховання стають обтяжливими, травматичними, їх слід нівелювати (Образцова, 2015).

Німецький соціолог, філософ, соціальний психолог, психоаналітик Е. Фромм (1900-1980) (Сурженко, 2011) виділяв два типи батьківської любові до дітей - батьківську і материнську. Материнська любов безумовна, мати любить дитину за те, що вона є, незалежно від її заслуг і здібностей. Батьківську ж любов Е. Фромм вважав обумовленою, батько любить дитину за те, що схожа на нього, сумлінно виконує свої обов'язки. Негативною стороною материнської любові $\epsilon$ той факт, що якщо мати любить дитину, то вона отримує міцну психологічну опору на все подальше життя, якщо ж любові немає, то іï вже не можна домогтися, створити штучно. Негативним чинником батьківської любові $\epsilon$ те, що від дитини потрібна обов'язкова слухняність, аби отримати любов батька, а неслухняність - це гріх. Позитивна сторона полягає в тому, що дитина може працювати заради батьківської любові. Найціннішим для дитини в батьківській любові $€$ можливість дорослішання: не просто бути любимим своїми батьками, а створювати любов самій. Дитина вчиться бачити в батьках і близьких людях не лише джерело задоволення своїх власних бажань і потреб, але i шанувати цілі і бажання інших людей. «Люблячи, людина покидає в'язницю своєї самотності та ізоляції. Людина переживає щастя єднання, злиття», - писав вчений (Сурженко, 2011). Російський дослідник спадщини 
Е. Фромма С. Степанов на основі теорії вченого спроєктував три типи любові, виділені Е. Фроммом, на три основні стилі сімейного виховання: авторитарний, ліберальний i демократичний. Батьківський тип батьківської любові він співвідніс 3 авторитарним, а материнський - 3 ліберальним і вважає, що «ідеалом служить золота середина - демократичний стиль, у якому відсутні крайнощі» (Сурженко, 2011).

Німецький соціолог Рене Кеніг (1906-1992) обстоював ідею всестороннього вивчення сім’ї, ролі батька і матері у вихованні дитини (Мануильская, 2009).

Оригінальне пояснення культуровідповідного виховання знаходимо в доробках німецького науковця К. Молленхауера (1928-1998). 3 середини XX ст. відбулася зміна структури сім'ї. Якщо середина XIX ст. означилася індустріалізацією та появою класичного образу родини, то в період Третього рейху сім'я цілком підпорядковувалася державним законам, поступово ставала ядром держави. Серед функції сім'ї в цей період найголовніша - функція соціалізації. Первинна соціалізація в К. Молленхауера асоціюється із сімейним вихованням, у якому дитина отримує початкові задатки для того, щоб зрозуміти всі тонкощі суспільного життя. У праці «Сімейне виховання» автором зазначено, що дитина в процесі батьківського виховання «освоює певну, необхідну ій кількість цінностей, соціальних ролей і норм» (Клим, 2013).

Книга К. Молленхауера (1975) під назвою «Шкідливість сімейного виховання для батьків, дітей, держави» стала маніфестом традиціоналізму. У цій праці німецький педагог схарактеризував традиційну педагогіку як складову частину реформаторства. Педагог стверджував, що авторитаризм, поєднаний у сімейному вихованні 3 мудрістю, спрямований суто на благо дитини: «... сучасне виховання в цивілізованому житті може виростити перспективну для суспільства людину, яка забезпечить добробут для себе і навколишніх». Поняття принципу свободи у виховання у автора відрізняється самоцінністю без смислових деривацій і пов'язується з трудовою діяльністю. Завдання матері керувати навчальною діяльністю дитини, економічне становище не повинно впливати на атмосферу у родині: «Більшість дітей у німецькому суспільстві виховуються в бідних, фінансово нестабільних сім'ях, і це не означає, що вони менш виховані, ніж інші. Навпаки, діти в таких сім'ях зусиллями батьків виховуються великодушними, хоробрими» (Тулупова, 2003)

Натомість німецький соціолог і політичний філософ Ульріх Бек (19442015), визначаючи перспективи змін суспільства, які з'являються в результаті взаємодії символічного й фізичного світів у контексті модернізаційних ризиків, вважав, що в сім'ї, яка, власне, $є$ втіленням взаємодії символічного й фізичного начал, модернізаційні ризики стосуються як символічного, так і фізичного компонента сім'ї, а так само способів їх взаємодії. Символічне начало сім’ї втілюється у феномені споріднення, причому споріднення мається на увазі будьякого типу: кревне, соціальне, в шлюбі. Споріднення містить у собі компоненти формальні й емоційні.

Як результат, У. Бек (2000) визначив такі сім типів сім'ї:

1) традиційна сім'я з батьками і дітьми;

2) розведені батьки-одинаки або батьки, що не знаходяться у шлюбі;

3) patchwork сім'ї (сім'ї у другому шлюбі з дітьми з попереднього шлюбу);

4) бінаціональні сім'ї з різних культур;

5) сім'ї з прийомними дітьми;

6) діти з гомосексуальними батьками; 
7) великі, кланові сім'ї.

Німецька дослідниця сім'ї Хельга Цайхер в соціологічному есе «Дитина в суспільстві та дитинство в соціології» (1996) вперше звернула увагу на роль дитини в суспільстві й запропонувала відійти від дослідження процесів соціалізації та звернутись до інших проблем, пов'язаних 3 життям неповнолітніх у соціумі (Клименко, 2013). На іiї думку, дорослі створюють у міському середовищі «острівці дитинства» - дитячі й підліткові клуби, рекреаційні розважальні центри, спортивні й ігрові майданчики й т. П. Подібна «інсуляризація» (термін Х. Цайхер) дитинства, з одного боку, створює ефект захищеності дітей від зовнішніх ризиків, а з іншого - призводить до обмеження їхньої мобільності, утруднення процесу формування необхідних соціальних навичок.

Сучасний німецький педагог Г. Гудджонс у праці «Четверта епоха - протест реформаторської педагогіки» (2001), аналізуючи конфлікт культур в Німеччині, стверджує, що «критика культури минулого часу разом із великомасштабними суспільними та соціальними змінами, а їх у Німеччині було на той час доволі», зумовили так звану «оккультуризацію у вихованні», пояснюючи цим процес успішного освоєння культурних набутків у вихованні. Для того, аби зрозуміти соціальне наслідування, потрібно простежити як індивідуальні й родовобіологічні ознаки, так i досвід батьків. Педагог разом 3 біологічною «сформованістю» радить акумулювати зусилля батьків і визнавати дитину як «представника роду, типового для свого соціуму».

Своєю чергою, сучасний німецький історик, дослідниця родинного виховання та сімейної політики Німеччини Б. Боїз вважає, що в Німеччині тривалий час існував історичний міф щодо багатодітних сімей, який виник на основі аналізу архівних фотографій, де зображувалася значна кількість дітей. Науковець грунтовно описує тенденцію до зростання в Німеччині так званих змішаних сімей (patchwork Familien), поява яких була пов'язана зі зменшенням середньої тривалості життя чоловіків (до 35,6р.) і жінок (до 44,8р.), що спостерігалася на початку 1900-х рр. Власне тому цілком нормальним вважалося одружуватися декілька разів, що стало менш поширеним надалі (Клим, 2013).

Висновки і перспективи подальших розвідок. Отже, на основі здійсненого аналізу проблеми сімейного виховання в контексті німецької філософськопедагогічної спадщини доведено, що теорія й практика виховання дітей у сім’ї в історичній ретроспективі вибудовувалась і підлягала логіці загальної теорії й практики виховання, хоча й мала свої особливості, спричинені як об'єктивними, так і суб'єктивними чинниками, які утворювали відповідну модель виховання дітей в країні.

Характеристика поглядів на виховання дитини в німецькій сім’ї філософів і педагогів (I. Канта, Г. Гегеля, Вільгельма фон Гумбольдта, Й. Ф. Гербарта, А. Дістервега, Ф. Фребеля, Пауля Антона де Лагарда, В. Лайа, Р. Штайнера, Ю. Лангбена, Ф. Кроума, Вільяма Віндельбанда, Отто Вільмана, Густава Адольфа Лінднера, Пауля Наторпа, Гуго Гаудіга, Бертольда Отто, Е. Шпрангера, Зігмунда Бернфельда, Е. Фромма, Рене Кеніга, К. Молленхауера, Ульріха Бека, Хельги Цайхер, Г. Гудджонса, Б. Боїза) дала можливість для висновку про те, що під впливом ідей видатних філософів та педагогів у Німеччині відбулись якісні зрушення у сприйнятті сімейного виховання: від суворого й аскетичного у Середньовіччі, гуманного в епоху Відродження та Реформації, чітко організованого в епоху Нового Часу та Просвітництва до усвідомлення 
сімейного виховання як одного 3 найвідповідальніших завдань німецького суспільства на початку XXI ст. Проблеми сімейного виховання - один 3 найбільш досліджуваних теоретичних аспектів німецької гуманітарної науки, який розробляють сьогодні філософи, педагоги, психологи, соціологи й спеціалісти інших галузей науки.

\section{СПИСОК ВИКОРИСТАНИХ ДЖЕРЕЛ}

Барило, О. (2004). Ідеї вільного виховання в реформаторській педагогіці кіния XIX - першої третини XX століття. Кандидат педагогічних наук. Національний педагогічний ун-т ім. М. П. Драгоманова.

Чирікова, Г. (2011). Проблеми сімейного виховання молодших школярів у Німеччині. Кандидат педагогічних наук. Луганський національний університет ім. Т. Шевченка.

Сурженко, О. (2011). Сучасні тенденції сімейного виховання та система цінностей у німецькій педагогіці. Духовність особистості: методологія, теорія і практика, 3, с. 147-159.

Клим, М. (2014). Сімейне виховання у німецьких дослідницьких студіях крізь призму ретроспективного дискурсу кінця XIX - початку XX століття. Людинознавчі студії. Педагогіка, 29(2), с. 103-111.

Федчишин, Н. О., Пермякова, О. Г. (2019). Роль родини й сімейного виховання в організації освітнього процесу Німеччини і Франції: історія та досвід. Медична освіта, 1, с.181-186.

Воробьёв, Н., Шачина, А. (2005). Система нравственного воспитания И. Канта. Педагогика, 5, с. 109-117.

Кант, И. (1990). Родительское право. Семья: Книга для чтения. [сост.: И. С. Андреева, А. В. Гулыга]. Москва: Политиздат, Кн. 2, С. 128-129.

Гегель, (1990) Лишь семья как целое представляет личность. Семья: Книга для чтения. [сост. : И. С. Андреева, А. В. Гулыга]. Москва: Политиздат, 1990. Кн. 2. с. $143-145$.

Гумбольдт, В. Ф. (1992). Идеи к опыту, определяющему границы деятельности государства. Величие здравого смысла. Человек эпохи просвещения: Москва: Просвещение, 1992. с. 48-53.

Кузьмінський, А. та Омеляненко, В. (2006). Педагогіка родинного виховання. Київ: Знання. 324 с.

Луков, В. (2005). Парадигмы воспитания. Гуманитарные науки: теория и методология, 3, с.139-151.

Федчишин, Н. (2015). Роль родини та сімейного виховання в організації освітнього процесу Німеччини в контексті гербартіанської педагогіки. В: Всеукраїнської наукової конференція Сучасна германістика та романістика: мова в контексті культури. Бердянськ: Видавець: Ткачук О.В., с. 196-200.

Дистервег, А. (1956). Избранные педагогические сочинения. Москва, 432 с.

Фребель, Ф. (1906). Избранные сочинения. Воспитание человека. Москва. Том I. 104 c.

Фребель, Ф. (2001). Будем жить для своих детей [сост. и пред. Л. М. Волобуева]. Москва: Карапуз. 287 с.

Коваленко, Є. та Бєлкіна, Н. (2006). Історія зарубіжної педагогіки. Київ: Центр навчальної літератури. 664 с.

Штайнер, Р. (2006). Оновлення педагогіки. Історія зарубіжної педагогіки. заг. ред. С. І. Коваленко. Київ: Центр навчальної літератури. с.561-578. 
Anthroposophische Pädagogik und ihre Voraussentzungen. 5 Lectures. 1924. S. 309-312.

Клим, М. (2013). Парадигма авторитаризму у координатах розвитку традиційної сімейної педагогіки Німеччини (1895 - 1933 рр.). Perspektywy rozwoju nauki. Zbior raportow naukowych. Gdansk: Wydawca: Sp. z o.o. "Diamond traiding tour". s. $45-48$.

Беленцов, С. (2019). Бертольд Отто и его школа свободного воспитания. Вестник ПСТГУ. Педагогика. Психология, Volume 4(55). URL: https://cyberleninka.ru/article/n/bertold-otto-i-ego-shkola-svobodnogo-vospitaniya [Дата звернення 6 жовтня 2 020].

Бернфельд, 3. (2014). Сізіф, або Межі виховання. Зігфрід Бернфельд; пер. 3 нім.: Наталії Дашко, Ярослава Лопушанського. Дрогобич; Інсбрук: Посвіт, 146 с.

Образцова, Л. (2015). Психоаналитическая педагогика Зигфрида Бернфельда. Педагогика, 4. с. 109-117.

Мануильская К. (2009). Кёниг. В: Большая российская энциклопедия, Москва. с. 561.

Mollenhauer, K. (1975). Die Familienerziehung. München: Juventa Verlag, S. 1315

Тулупова, О. (2003). Проблема соотношения обучения и воспитания в педагогическом наследии И. Ф. Гербарта. Педагогика, 5, с. 71-78.

Бек, У. (2000). Общество риска. На пути к другому модерну. Москва: Прогресс-Традиция. 384 с

Клименко, О. (2013). Особливості солідарної моделі соціальної підтримки дітей. Грані, Volume 10, с. 112-117. URL: http://nbuv.gov.ua/UJRN/Grani_2013_10_20 [Дата звернення 15 жовтня 2020].

Gudjons, G. (2001). Vierte Epoche: Der Protest - die Reformpädagogik. Grundwissen Padagogik. Gudrun Ixmeier. S. 26-28.

\section{REFERENCES}

Barylo, O. (2004). Idei vilnoho vykhovannia $v$ reformatorskii pedahohitsi kintsia $X I X$ - pershoi tretyny XX stolittia. [Ideas of free education in the reformist pedagogy of the end of the $19^{\text {th }}$ - the first third of the $21^{\text {th }}$ century.] Kandydat pedahohichnykh nauk. Natsionalnyi pedahohichnyi un-t im. M. P. Drahomanova. [in Ukrainian]

Chyrikova, H. (2011). Problemy simeinoho vykhovannia molodshykh shkoliariv $u$ Nimechchyni. [Problems of family upbringing of junior schoolchildren in Germany.] Kandydat pedahohichnykh nauk. Luhanskyi natsionalnyi universytet im. T. Shevchenka. [in Ukrainian]

Surzhenko, O. (2011). Suchasni tendentsii simeinoho vykhovannia ta systema tsinnostei u nimetskii pedahohitsi. [Modern trends in family education and the system of values in German pedagogy.] Dukhovnist osobystosti: metodolohiia, teoriia $i$ praktyka, 3, s. 147-159. [in Ukrainian]

Klym, M. (2014). Simeine vykhovannia u nimetskykh doslidnytskykh studiiakh kriz pryzmu retrospektyvnoho dyskursu kintsia XIX - pochatku XX stolittia. [Family education in German research studies in the context of retrospective discourse of the end of the $19^{\text {th }}$ - at the beginning of the $20^{\text {th }}$ century] Liudynoznavchi studii. Pedahohika, 29(2), s. 103-111. [in Ukrainian]

Fedchyshyn, N. O., Permiakova, O. H. (2019). Rol rodyny y simeinoho vykhovannia $\mathrm{v}$ orhanizatsii osvitnoho protsesu Nimechchyny i Frantsii: istoriia ta dosvid. [The role of family and family upbringing in the organization of the 
educational process in Germany and France: history and experience.] Medychna osvita, 1, s.181-186. [in Ukrainian]

Voroboyv, N., Shachwna, A. (2005). Systema nravstvennono vospшtaniya Y. Kanta. [Kant's system of moral education.] Pedagogika, 5, s. 109-117. [in Russian]

Kant, Y. (1990). Rodytelskoe pravo. [Parental rights] Semia: Knyha dlia chtenyia. [sost. : Y. S. Andreeva, A. V. Gulyga]. Moskva: Politizdat, Kn. 2, S. 128-129. [in Russian]

Hehel. (1990) Lish semia kak tseloe predstavlyaet lichnost. [Only the family as a whole represents the individual] Semia: Kniga dlia chteniya. [sost. : Y. S. Andreeva, A. V. Gulyga]. Moskva: Politizdat, 1990. Kn. 2. s. 143-145. [in Russian]

Humboldt, V. (1992). Idei k opytu, opredelyayushchemu granitsy deiatelnosti gosudarstva. [Ideas for experience that determine the boundaries of the state] Velichie zdravogo smysla. Chelovek epokhi prosveshcheniya: Moskva: Prosveshcheniye, 1992. s. 48-53. [in Russian]

Kuzminskii, A. ta Omelianenko, V. (2006). Pedahohika rodynnoho vykhovannia. [Pedagogy of family education.] Kyiv: Znannia. 324 s. [in Ukrainian]

Lukov, V. (2005). Paradigmy vospytaniya. [Paradigms of education] Gumanitarnye nauky: teoriya i metodologiya, 3, s.139-151. [in Russian]

Fedchyshyn, N. (2015). Rol rodyny ta simeinoho vykhovannia $v$ orhanizatsii osvitnoho protsesu Nimechchyny v konteksti herbartianskoi pedahohiky. [The role of family and family upbringing in the organization of the educational process in Germany in the context of Herbartian pedagogy] V: Vseukrainskoi naukovoi konferentsiia Suchasna hermanistyka ta romanistyka: mova $v$ konteksti kultury. Berdiansk: Vydavets: Tkachuk O.V., s. 196-200. [in Ukrainian]

Disterveg, A. (1956). Izbrannye pedagogicheskge sochineniya. [Selected pedagogical writings] Moskva, 432 s. [in Russian]

Frebel, F. (1906). Izbrannye sochyneniya. Vospitane cheloveka. . [Selected Works. Raising a person.] Moskva. Tom I. 104 s. [in Russian]

Frebel, F. (2001). Budem zhyt dlia svoikh detey. [Let's live for our children] [cost. y pred. L. M. Volobueva]. Moskva: Karapuz. 287 s. [in Russian]

Kovalenko, Ye. ta Bielkina, N. (2006). Istoriia zarubizhnoi pedahohiky. [History of foreign pedagogy] Kyiv: Tsentr navchalnoi literatury. 664 s. [in Ukrainian]

Shtainer, R. (2006). Onovlennia pedahohiky. Istoriia zarubizhnoi pedahohiky. [Updating pedagogy. History of foreign pedagogy] zah. red. Ye. I. Kovalenko. Kyiv: Tsentr navchalnoi literatury. s.561-578. [in Ukrainian]

Anthroposophische Pädagogik und ihre Voraussentzungen. [Anthroposophic pedagogy and its requirements. 5 lectures]. Lectures. Bern, 1924. S. 309-312. [in German]

Klym, M. (2013). Paradyhma avtorytaryzmu u koordynatakh rozvytku tradytsiinoi simeinoi pedahohiky Nimechchyny $(1895$ - 1933 rr.). [The paradigm of authoritarianism in the coordinates of the development of traditional family pedagogy in Germany (1895 - 1933).] Perspektywy rozwoju nauki. Zbior raportow naukowych. Gdansk: Wydawca: Sp. z o.o. "Diamond traiding tour". s. 45 - 48. [in Ukrainian]

Belentsov, S. (2019). Bertold Otto i ego shkola svobodnogo vospitaniya. [Berthold Otto and his school of free education.] Vestnik PSTHU. Pedagogika. Psikhologyia, Volume 4(55). URL: https://cyberleninka.ru/article/n/bertold-otto-i-ego-shkolasvobodnogo-vospitaniya [Data zvernennia 6 zhovtnia 2 020]. [in Russian] 
Bernfeld, Z. (2014). Sizif, abo Mezhi vykhovannia. [Sisyphus, or the Limits of Education.] Zihfrid Bernfeld; per. z nim.: Natalii Dashko, Yaroslava Lopushanskoho. Drohobych; Insbruk: Posvit, 146 s. [in Ukrainian]

Obraztsova, L. (2015). Psikhoanaliticheskaya pedagogika Zigfrida Bernfelda. [Siegfried Bernfeld's Psychoanalytic Pedagogy.] Pedagogika, 4. s. 109-117. [in Russian]

Manuylskaya K. (2009). Kënyh. [Koenig].V: Bolshaia rossiyskaya entsyklopediya, Moskva. s. 561. [in Russian]

Mollenhauer, K. (1975). Die Familienerziehung. [The family education]. München: Juventa Verlag, S. 13-15 [in German]

Tulupova, O. (2003). Problema sootnosheniya obucheniya i vospitaniya v pedagogicheskom nasledii I. F. Gerbarta. [The problem of the relationship between education and upbringing in the pedagogical heritage of I.F. Herbart] Pedagogika, 5, s. 71-78. [in Russian]

Bek, U. (2000). Obshchestvo riska. Na puti k drugomu modernu. [Risk society. On the way to another modernity] Moskva: Progress-Traditsiya. 384 s. [in Russian]

Klymenko, O. (2013). Osoblyvosti solidarnoi modeli sotsialnoi pidtrymky ditei. [Features of the solidarity model of social support for children.] Hrani, Volume 10, s. 112-117. Rezhym dostupu: http://nbuv.gov.ua/UJRN/Grani_2013_10_20 [Data zvernennia 15 zhovtnia 2020]. [in Ukrainian]

Gudjons, G. (2001). Vierte Epoche: Der Protest - die Reformpädagogik [Fourth epoch: the protest - reform pedagogy]. Grundwissen Padagogik. Gudrun Ixmeier. S. 26-28. [in German]

\title{
ISSUES OF FAMILY EDUCATION IN THE CONTEXT OF THE PHILOSOPHICAL AND PEDAGOGICAL HERITAGE OF GERMANY (MIDLLE of the $18^{\text {th }}-$ BEGINNINGS OF THE $21^{\text {th }}$ CENTURY)
}

\author{
Oksana Petrenko \\ Doctor of Sciences (in Pedagogy), \\ Professor, Head at the Department of Theory and Methods of Education, \\ Rivne State University for the Humanities, \\ Rivne, Ukraine \\ ORCID: 0000-0001-6906-3542, \\ e-mail: o.b.petrenko@gmail.com
}

\begin{abstract}
The article provides a holistic historical and pedagogical analysis of the issues of family education in the context of the philosophical and pedagogical heritage of Germany from the middle of the 18th to the beginning of the 21st century. Since the content, goals and methods of raising a child in the family have always been determined and determins nowadays by the requirements of the time, the specifics of education due to the level of economic development, ideological characteristics, culture, religion that dominate in a particular country/ Especially interesting in this context is Germany, in which a kind of system of family education with unique traditions has developed

Views on the upbringing of a child in a German family of the following philosophers and teachers of a certain period are characterized in the article (I. Kant, G. Hegel, Wilhelm von Humboldt, J.F Herbart, A. Disterweg, F. Froebel, Paul Anton de Lagarde, W. Lay, R. Steiner, J. Langben, F. Crow, William Windelband, Otto
\end{abstract}


Wilman, Gustav Adolf Lindner, Paul Natorp, Hugo Gaudig, Berthold Otto, E. Spranger, Sigmund Bernfeld, E. Fromm, Rene Koenig Mollenhauer, Ulrich Beck, Helga Zeicher, G. Gudjons, B. Boise).Based on the analysis, it is concluded that under the influence of the ideas of prominent philosophers and educators in Germany there were qualitative changes in the perception of family upbringing: from strict and ascetic in the Middle Ages, humane in the Renaissance and Reformation, clearly organized in modern times and modern times; awareness of family upbringing as one of the most important tasks of German society at the beginning of the 21 century. It has been found that the problem of family upbringing is one of the most studied theoretical aspects of the German humanities, which is being developed nowadays by philosophers, educators, psychologists, sociologists and specialists in other fields of science.

Key words: family upbringing, German family, German philosophy, German pedagogy, philosophical and pedagogical heritage.

Стаття надійшла до редакиії 05. 10. 2020 р. 